Dilson JatAhy FonseCA NetO

\title{
DA COMPRA E VENDA A CONTENTO NA COMPILAÇÃO DE JUSTINIANO
}

(Dissertação de Mestrado)

Orientador:

Prof. Titular Eduardo Cesar Silveira Vita Marchi

FACUldade DE DiReito da Universidade de SÃo PaUlo

$$
\text { SÃo PAUlO }
$$


BANCA EXAMINADORA 
À minha mãe, obrigado pela força, Ao meu pai, obrigado pelo exemplo, À minha avó, as palavras não são suficientes. 
"Iuri operam daturum prius nosse oportet, unde nomen iuris descendat. est autem a iustitia appellatum: nam, ut eleganter celsus definit, ius est ars boni et aequi."

Ulpiano, libro I, Institutionum. 


\section{RESUMO}

A Compra e Venda a Contento é um instituto bastante utilizado nas relações comerciais ainda nos dias modernos. Já na antiguidade, os Compiladores do Corpus Iures Civilis também notaram a utilização de um pacto "ut, si displicuisset, inempta esset", i.e., "tal que, se desagradar, seja tida como não comprada", espalhando por todo o Digesto referências a tal pactum. Esse é o tema dessa monografia.

Diferente da in diem addictio e da lege commissoria, que receberam um Título do Digesto cada, o pacto ora estudado não recebeu nome - reconhecível - dos jurisconsultos antigos. Nem por isso há que se discutir a sua importância: nas Institutas de Justiniano, os Compiladores utilizam este pacto especificamente para apontar a possibilidade de que a Compra fosse realizada condicionalmente (Inst. 3, 23, 4).

Para realizar tal estudo, essa monografia se inicia com uma análise preliminar da Compra e Venda; estabelecem-se os elementos básicos - o preço, a coisa e o consentimento -, bem como uma descrição dos principais pacta que se adicionam ao contrato. Análise especial é feita da emptio ad gustum, bastante confundida como se a condição fosse a mesma.

Em seguida, a monografia passa à definição do que se entendeu por pactum displicentiae, nome dado pela moderna doutrina romanista ao pacto descrito acima. Apontam-se os principais fragmentos que tratam da Compra e Venda a Contento, buscando assim alcançar uma definição básica do pacto. Apontam-se também as formas como o pacto é realizado nas fontes, seja as palavras com que os jurisconsultos os descrevem, bem como as consequências advinda. Antes de concluir o terceiro capítulo, há uma breve análise das ações ofertadas pelos jurisconsultos para garantir os direitos das partes.

No quarto capítulo é feita uma análise das condições em Direito Romano: suas formas suspensiva e resolutiva e, em especial quanto a esta, como eram incluídas nos contratos. Analisa-se, então, a forma da condição do pactum displicentiae, se era sempre resolutivo, se necessariamente suspensivo ou se podia ser de ambas as formas. Neste capítulo estuda-se ainda outras formas de condição, a sua satisfação fictícia etc.

No quinto capítulo, a monografia analisa o periculum res venditae, especialmente quanto à condição suspensiva. $\mathrm{O}$ faz porque esse pactum apresenta situação peculiar: em que pese haja contrato e a coisa esteja na posse do comprador, ainda não houve 
transferência da propriedade. Analisa-se ainda a questão da retroatividade da condição, buscando saber em que momento se transfere o periculum ao comprador.

Enfim, passa-se à análise de três fragmentos extremamente interessantes, bem como de grande utilidade para a compreensão do instituto ora estudado. No primeiro, foca-se na questão da responsabilidade pela coisa vendida, sem descuidar da questão condicional. No segundo, analisa-se o limite da condição e a extensão da prova pelo comprador. No terceiro, o periculum, fazendo-se a contraposição entre a condição suspensiva e a condição resolutiva. 


\begin{abstract}
The Purchase and Sale on Satisfaction Condition is an institute widely used in commercial relations even in modern days. Already in the antiquity, the Compilers of the Corpus Civilis Iures had noted the use of a pact "ut, si displicuisset, inempta esset" ("such that, if displeased, be regarded as not purchased"), spreading references of such pactum across the Digest. This is the theme of this monograph.

Unlike the in diem addictio and the commissoria lege, which received respective Titles in the Digest, the studied pact did not receive a - recognizable - name from the ancient jurists. Even so, its importance must not be doubted: in Justinian's Institutes, the compilers use specifically this covenant to point the possibility that the purchase was stablished conditionally (Inst 3, 23, 4).

Thus, to perform such a study, this monograph begins with a preliminary analysis of Sales contract; the basic elements - price, the thing which is sold or bought and the consent - are described, as well are described the pacta that are added to the Purchase and Sale. A special analysis is made of the emptio ad gustum, which creates quite a confusion, many times being understood as if it was the same condition.

Next, the monograph addresses what is understood by pactum displicentiae, the name given by modern doctrine of Roman Law to the above described pactum. Pointing the main fragments that deals with its topic, it seeks to achieve a basic definition of the covenant. The monograph also points out the forms in which the covenant is held in the sources, the words that the jurists use to describe it and the consequences arisen. Before ending the third chapter, there is a brief analysis of the actions offered by the jurists to ensure the rights of the parties.

The fourth chapter makes an analysis of the conditions under Roman law: its suspensive and resolutive forms, and in particular about the latter, which were included in the contracts. The next step is to analyze the form of the displicentiae pactum condition; if it was always resolutive, necessarily suspensive, or if it could be formed in both ways. This chapter still studied other forms of condition, especially their fictitious satisfaction.

In the fifth chapter, the monograph analyzes the periculum res venditae, with especially consideration of the suspensive condition. This analysis is made because this pactum presents a peculiar situation: in spite of the contract and the fact that the thing is in the possession of the buyer, there has been no transfer of ownership. Further on, it
\end{abstract}


studies the retroactivity of the condition, seeking to establish when it transfers the periculum to the buyer.

At last, it moves on to analyze three extremely interesting fragments, as well as very useful for understanding the institute studied herein. The first focuses on the issue of liability for the thing sold, without neglecting the conditional issue. The second analyses the boundaries of the condition and the extent of the buyer's freedom to experiment. The third addresses the periculum, making the contrast between the suspensive and the resolutive conditions. 